\title{
The Truth and Fiction About (Turkey's) Human Rights Politics
}

\author{
Umit Cizre
}

One major reason why I eagerly accepted the offer by the guest editors of this special issue to write a piece on the human rights problem in Turkey was to confront, reflect upon and deconstruct my own nagging unease about the human rights discourse and regime, globally and in Turkey. That my sense of discomfort is largely related to the Turkish public sphere's lack of unconditional affiliation with human rights as a cause and practice is obvious. But there is more to it than being disenchanted with the sorry state of the existing human rights implementation in a specific geography. It also has to do with wanting to rethink critically the accepted wisdoms of the issue, highlight the links among conceptualization, ideology/power dimensions and implementation, and analyze their impact on human rights discourse in general.

Human rights values have not aroused Turkey's centrist-liberal passions fully. Nor have they been translated into popular discourse. For the conservative-nationalist position, the concept has no empirical reality outside a shared moral code that can only come with being part of a "community" where duties take precedence over rights. For Turkey's millions in the urban middle classes, the human rights landscape is still unsafe, not worth the time and energy to extend sympathy, support and commitment in terms of the future returns it offers. Only some professional segments that perceive integration with global entities and dynamics in their own objective interests, intellectual dissidents, and those who have suffered materially and psychologically under human rights abuses have engaged with the cause of human rights with some zeal and devotion. Given this wide spectrum of aversion to human rights as a cause, I, therefore, have decided to amalgamate a solitary academic introspection with a Turkey-centered soul-searching into the limitations, shortcomings and imperfections of human rights politics. In doing this, I will try to establish connections between the broader global processes of a human rights regime and a serious concern for theory from a critical perspective. 
At a time when the language of human rights is even more potent than that of democracy and is being used as an instrument to legitimize even illegitimate leaders, movements and causes, Turkey has galvanized the international community by its omissions and violations rather than affirmations of human rights. Under such circumstances, a critical sensibility toward the human rights universe may cause a huge embarrassment for the critic and may seem out of sync with the harsh reality of Turkish life. One may be tempted to be grateful with the operation of normative foundations of human rights which, however imperfectly implemented, mayby its very nature-still help to prevent members of the society from suffering outright repression, pain and indignities: a human rights regime generates a politics of equal dignity to everyone by ascribing an identical basket of rights simply because the basket is limited to that aspect of everyone that is assumed to be universally the same, namely, humans' status as rational agents. ${ }^{1}$ The most precious content of the basket is the notion of an"empowered individual"regardless of age, sex, race, geography, wealth, culture, which indicates the right of every individual to control her/his own destiny and fulfil his/her potential to the fullest extent without intervention.

What contributes to the risks of being critical of the concept and its enforcement is the seeming moves toward some positive"changes toward a change" in Turkey's grim human rights landscape, under external pressure. Statistics of the Human Rights Foundation of Turkey (Insan Haklari VakfiIHV) ${ }^{2}$ released in February 2000 bear witness to this trend: "all forms of violations of the right to life have declined in some degree in the last 5 years, ${ }^{\prime \prime}$ and the prosecution of the state-centered perpetrators of torture and ill-treatment is no longer an unthinkable prospect. On this point, Ercan Demir, the chairman of the Izmir branch of the Turkish Human Rights Association (Insan Haklari Dernegi- IHD), a sister organization to the IHV, confirms the trend by stating that the global pressure on Turkey to correct her human rights image seems to work. ${ }^{4}$ As these are the two most prominent NGOs in Turkey at the forefront of human rights advocacy, speaking forthrightly on human rights abuses and sometimes falling victim to state repression themselves, their findings lend more reliable support to the view that positive changes are taking place in the human rights universe and that it is counterintuitive to be critical of the concept at this juncture. The findings also capture the prevalent belief that expanded relations with the West-in particular, integration into the European Union (EU)-will, in time, provide the impetus for human rights to act as a catalyst to emancipate politics from authoritarian legacies, civilianize it, help establish the rule of law, restore human dignity, end the abuse of power within the state apparatus, and extinguish the passions of hatred and violence in society, which have been growing parallel to the war in the southeast against the Kurdish nationalist movement. 
However, what constitutes one major concern of this study is the coalescence of all parties to international and domestic human rights systems around the metaphor of an "Archimedean leverage," ${ }^{5}$ that is, a conceptualization of human rights as a baseline condition and a fact rather than an historical-political-philosophical issue. This means that, more often than not, human rights is conceived in all-or-nothing terms, elevated to the level of a metaphysical and definitive solution to the problems of democracy, rather than one possible component of a strategy of a liberal political agenda. By perceiving human rights not as a condition fundamental to wider political and social developments but as an end in itself, human rights discourse, globally and nationally, simplifies the complexity of the real world. This metaphoric usage of human rights also plays a significant role in shaping the character of the concept in an apolitical, ahistorical and decontextualized way which impedes attempts to achieve what is commonly accepted as the three-tier processes of a human rights regime: standard setting, monitoring and enforcement. Problematizing human rights as a dependent variable, however, is not to stop appreciating its real virtues. What it means is to enhance our understanding of the concept not as a "text," but within a "context," by establishing its rightful connections with the motions of "politics" via emphasizing its "historicity."

\section{Problem 1-Conviction by Default? Clarifying the Language of Human Rights}

The intellectual debate in Turkey on how to improve the human rights situation raises pertinent questions about the problem of what the concept really entails. A pioneering meeting on October 14, 1999 organized by the then-minister of state responsible for human rights, Mehmet Ali Irtemcelik, with human rights advocacy groups in Turkey representing a variety of world views, exemplifies the issue at stake: all speakers coming from liberal, leftwing and Islamist positions seem to have slipped into an excessively legalistic discourse in discussing the possible policy improvements. ${ }^{6}$ The central divide between them was whether to change the constitution of 1982 in its entirety or opt for incremental legal changes to promote individual rights and democratic processes in an unrestricted public sphere. Although the views expressed in the meeting contain important insights, this legalistic vision does not seem-as some of the speakers admit-to present a very compelling case for the programmatic feasibility of human rights. The chief reason for this is that this position is informed by an understanding of human rights as a "juridical technique" rather than a "political-normative substance of government". The distinction between these two positions has salience for the promotion of an agenda of human rights: while the former perspective isolates human rights as a given and is reductionist, the 
latter treats it as something that must be constructed, protected, and made part of the moral sensibility of the society and the ultimate foundation of the regime. Human rights as a bundle of legal reforms involves an "act of sacrifice" by the power-wielders, without addressing itself to the questions of structures of power and the strategies, motivations, characteristics, lifestyle choices, biographies and ideologies through which the power-wielding institutions may or may not be converted into self-sacrificing agents of reform. On the other hand, perceiving human rights as a political-normative commitment comes closer to an engagement in a bottom-up democracy-building discourse. Clearly, legal changes create the necessary although not sufficient conditions for the cultivation of human rights values as components of an overall framework of liberal democracy. Also, unless supplemented by a civil-normative-educative approach, they open the political space to "reform demagogues."

The implications of the muddle of what human rights policies should contain go beyond differences of perspectives on the fundamentals of the regime. It also seems to have given rise to two more crucial problems in the intellectual battle for human rights in Turkey. The first is an "inflation" in the repertoire of human rights, the other is a lack of awareness of the connections between human rights and what Professor Kucuradi calls"the world problems." 7 With regard to the first, the proliferation of human rights issues ranging from torture and arbitrary detention to hunger, illiteracy, child labor, child prostitution, women's rights, and deaths from lack of access to safe water, though sounding noble, turns human rights into empty rhetoric and undermines the effectiveness of their protection and promotion. The emergence of group rights on the global agenda as the depository of legitimacy for identity politics highlights the self-defeating aspect of human rights discourse when the meaning, possibilities and constraints of what these rights entail are not systematically thought out: then, human rights may work to the ${ }^{\prime \prime}$ detriment of the basic rights of other citizens... may cause damage to human rights and present attempts to restrict group interests as violations of human rights." ${ }^{8}$ It could be argued on the other hand that the concept enjoys the authority it does because of the absence of a clear-cut understanding of what it truly contains, and more so, by overstating the generality of its claims. If so, it raises the question as to whether the belief in human rights is out of conviction or by default.

If, as Professor Kucuradi puts it, human rights are not just"abstract assumptions deprived of cognitive ground," ${ }^{\prime \prime}$ their enforcement requires an understanding of the embeddedness of human consciousness in the politically determined socio-economic-conditions of a particular context. These conditions, in turn, reflect the structure of the global system of power in developed, underdeveloped or developing countries. There is a need to develop the awareness of the implications of some global consensus-like 
the Washington consensus that has turned into the dominant orthodoxy of the day-on the human consciousness: the consensus has hurt human rights by reproducing global and national inequality and by distorting the consciousness of the right to control one's own destiny in such a way as to fulfill one's potentialities to the fullest extent. In other words, although the ultimate value of human rights is the empowerment of the individual with regard to his/her own fate, this is contradicted by the prevailing conditions of neo-liberal globalization. To heighten one's awareness of the power hierarchy in the world which precludes human rights from being fully realized, does not, however, imply a theoretical affinity with those who attack the universalism of human rights as "phony" because it reflects the values of western civilization. This perspective explains the difficulties of enforcing a global human rights regime in culture-essentialist terms: human rights cannot be internalized by "outside cultures" with no elective affinity with the "insiders."But, to deny the universality of human rights, that is, to think that human rights are not common to all contexts on normative and operational levels, is to reinforce the oriental stereotyping which suffuses the western thought and which this denial intends to attack. This essentialist perspective also misses the fact that implementation of human rights can provide a leverage from which those who suffer from unequal distribution of power can wage a struggle against the global hegemons.

\section{Problem 2-Human Rights: An Apolitical Universe?}

The apolitical nature of the way human rights issues are dealt with captures the Turkish case by a number of trends which weaken the bases for their implementation. Foremost among these is the reduction of the human rights bundle to a reform rhetoric which ignores the root causes of human rights violations. Behind this discourse lies an understanding of human rights as ideology-free, and relatedly, a conception of polity and people as free from ideological bias/falsehood, thus, are"reasonable."More importantly, the background assumption of politics is as "administration" and the redress envisaged for human rights violations is legal changes.

There are a number of difficulties with this predominant discourse. The vital deficiency is the way human rights reformism acts as an effective smoke screen precluding (Turkey's ) fundamental political problems from being analyzed and resolved analytically and competently. For one thing, the reform rhetoric can play one component of human rights package against the others contained in the same bundle. The problem here is that highlighting some rights and undermining the others may serve to perpetuate the status quo. The best example is Turkey's 28 February 1997 soft-coupas some circles prefer to call it-when the military-dominated National Security Council (Milli Guvenlik Kurulu, or MGK) handed down the con- 
stitutionally elected coalition government of the day an 18-point list of measures to clamp down on"reactionary Islam" (irtica in Turkish) that forced the Prime Minister Necmettin Erbakan, the leader of the pro-Islamic Welfare Party (Refah Partisi) to resign. Since that date, there has been a threshold shift in the political autonomy of the Turkish military in its self-identified role as the custodian of the western and secular parameters of the regime. The principle of human rights that underpins political modernity is the "private" character of religion conceived as a matter of individual conscience that promotes individual autonomy. When considered against this understanding, Turkey's indirect coup conforms to the conceptualization of human rights in a modern polity as it was carried out to put an end to the infiltration, entrenchment and institutionalization of political Islam in the public space defined as schools, universities, government departments and the armed forces. It is this threat of spillover of Islam from private to public sphere which has legitimized a radical rise in the political role and significance of the Turkish military. Sacrificed in the process, however, are the other imperatives of the human rights basket. They include the military's subordination to democratic parliamentary control to ensure that individual autonomy cannot be decreed or imposed from above in such a way to endanger freedom of thought and expression. Moreover, contrary to the assumptions of the existence of a non-ideological human rights regime that underlines this perspective, what we end up with is a" politicized" human rights bundle not any different in essence from the high profile assigned to human rights by the Carter administration as part of the anti-communist crusade in the USA in the 1970s. ${ }^{10}$

Another problematic trend that the apolitical perspective introduces into contexts like Turkey is what is called the "monitoring strategy," the act of following up cases of human rights abuses by exposing them through the activities of international and national NGOs. Although this strategy paves the way to the formation of some valuable international pressure points for the norm-defying regimes to correct their human rights situation, it works best under the assumption that human rights violations in a given context are not the rule but the exceptions, that is, they are not systematic because they grow out of the challenges against the state which normally occur sporadically. Once they are accepted as non-systematic, occasional torture and cases of disappearances can be remedied by initiating periodical reports published by international monitoring agencies usually prepared in cooperation with local NGOs to generate international pressure for launching legal reforms to improve the human rights universe. Yet, there is something amiss in this strategy: the empirical world provides evidence that in their dealings with human rights abuses, it is not always democracy but the strategic and economic interests of the pressuring entities that are paramount. In an interview, a high official of the IHV expressed to me the 
organization's strong distrust that its donor governments and human rights agencies promote human rights in Turkey in a self-serving manner to advance a variety of Western interests, selling arms to the Turkish Armed Forces (TAF) as part of the TAF's ambitious modernization program being the most important one. ${ }^{11}$ He further pointed out that beginning from 1998, the IHV has been under heavy pressure by Western governments to include in their annual reports the notion that the human rights situation in Turkey has improved. Moreover, the same official views the omission in the international reports of the unresolved problem of the forced evacuations of villages in the southeast by state security forces as evidence of a strategy not to alienate the Turkish government so as not to block Western political and economic interests.

Because it rests on such apolitical assumptions, Turkey's human rights rhetoric makes us believe that what the stark display of human rights violations reflect is irrational squabbles between politicians, feuding personalities, incompetent political gamesmanship which has given rise to disruptive movements like political Islam, fragmentation of the political spectrum and other"backward" aspects of Turkish political life as if they are the products of some essentialist mental constructs peculiar to this geography; whereas, these phenomena are the results, not the causes, of the fragility of Turkish devotion to democratic principles. In that sense, human rights discourse does not deal with the more profound aspects of politics lurking behind human rights violations.

\section{Turkey's Catch-22}

One aspect of "real politics" in which human rights are embedded is the entrapment of Turkish politics in a Catch-22 situation. Because human rights define a certain category of state identities which official Turkey has historically chosen to be on par with, its painful wait for membership in the $\mathrm{EU}$ is its own making. Moreover, the indignity of being kept waiting is the result of an irreversible decision. Put differently, given a long historical course of Turkey's commitment to Europeanization, no Turkish leader can sustain a consistent and durable anti-Western strategy for any length of time without the risk of losing support and prestige in the country. Thus, Turkey lacks the option that is open to some of its neighbors further south: when asked by the Danish TV in 1998 whether Morocco's desire to enter the then European Community also implied an acceptance of European democracy, King Hassan II, taking full advantage of a lack of tradition of dependency on a historic choice to be on par with the West, replied, "we are not Europeans, we do not accept democracy a l'europeenne."12

Even when its application for a candidate status for membership was denied in the 1997 Luxemburg European Council Meeting while 10 central 
and eastern European countries and Cyprus were allowed in, the official position in Turkey could not shift radically toward a different direction. The problematic of accession to Europe boils down to the fact that it is an identity-enforcement exercise. Mehmet Ali Irtemcelik, former minister of state responsible for human rights, voiced the non-negotiable character of this problematic, in dramatic terms perhaps, when he said, "Turkey's severance from the progressive race of civilization, and its acceptance of itself as a second-league state, society and people is unthinkable. This cannot be allowed to happen; we cannot allow this to happen."13

But then the question is why Turkey's search for a place under the Western sun is circumscribed and falls short of fulfilling her historic aspiration to be regarded as a reputable western state, even when this is somewhat confirmed by the December 1999 Helsinki European Council's decision to include Turkey among candidate countries. The Catch-22 position manifests itself here in two forms. First, the code that determines Turkey's accession path is the criteria agreed upon in the 1993 Copenhagen European Council meeting, according to which all applicant countries must achieve complete freedom of expression, human rights, respect for and protection of minorities, a non-intervening military in politics, and an efficient market economy. But the tragedy is that the regime and the EU sometimes seem to be at cross-purposes: while Turkey's sizable pro-European circles would like to enter the EU to obtain the benefits of democracy and prosperity ${ }^{14}$, the prevailing view among the EU bodies is that that the Turkish regime should qualify to join the EU only when it is regarded as democratic and prosperous. The "shaming" strategies the regime has been subjected to-or forced to put up with, depending on the perspective- on the issues of human rights, democracy and market records serve to demonstrate this impasse.

The next imbroglio again stems from linking a fully established human rights regime in Turkey with the issue of entry into Europe. There are ample signs that there is a clear split between those who see the achievement of human rights as part of a process evolving towards completing Turkey's incomplete democracy orientation and those who focus on human rightscum-accession to Europe as a muddled end goal polishing Turkey's image. The first group comprises liberal Europeanists, while the latter conservative secular stratum. The former group advocates a full range of democratization and blame the "resistance" put up by state organs for the failure to do so. They do not pay enough attention to the invisible dynamics between these bureaucratic organs of the state and society in such a way as to build popular support for the attempts to hold back the process. But if human rights is not just a matter of enactment and if the proponents of full democracy and human rights should have a modicum of public support behind them to achieve this goal, then there is an urgent need to understand 
the power strategy that the "resisting bodies"have established with society by addressing everyday social relations and practices that shape citizens' understanding of self, society, politics and the role of bureaucratic organs in their lives. By focusing on the democratization process superficially, the first group lacks a full understanding of the deeper dynamics of the process. The failure to distinguish between truth and illusion, so to speak, obscures the achievement of the end goal.

For the latter group, human rights and democracy are not the products of a choice but circumstance. By prioritizing the end goal of being in the first league, they obliterate the true process. Their main thesis is that democratic compromises to join the EU are too high a price to pay for maintaining a strong state capable of fighting against religious reactionism ("irtica") and separatist terror. When they suggest, as Faruk Bal, the Minister of State from the ultranationalist Nationalist Action Party does, that "we should enter the EU to reach contemporary standards... without allowing some quarters to employ them (human rights) as vehicles for hostility to the state and subversion... "15 the discourse on human rights, the means-andend argument and even the pro- EU direction turn into instruments to produce a politically correct language, rituals, gestures, and symbols in public life. The end result is that Turkey's full integration with Europe means all things to all people and the magic wand of human rights lacks an effective engagement with its norms: "secularists are as enthusiastic as Islamists, hoping that membership will guarantee Turkey's leaning toward the West. The generals imagine EU entry will safeguard Turkey's integrity, even as Kurdish separatists see their salvation in Europe's generous treatment of minorities. Nationalists see entry as an implicit confirmation of Turkey's greatness; liberals look to Europe to scotch such chauvinism. Politicians cannot wait to get their hands on aid for Turkey's deprived regions-whose inhabitants in turn cannot wait to emigrate to Berlin or Stockholm."16

To affirm faith in the dignity and worth of human beings on the basis of the sameness of human condition seems to open the Pandora's box of Turkish politics. But can contemporary human rights politics be isolated from a historical perspective? In fact, the promotion of human rights in Turkey is just another turn of the wheel in the long history of Turkish attempt to catch up with the West. If so, this brings us to a further flaw in the existing human rights discourse, which is its ahistorical nature.

\section{Problem 3-Human Rights: Metaphysics or History, Product of Good Times or Dire Days?}

At present, there are three characterizations that underpin the discussion of human rights in non-Western contexts. According to the first, it is 
true that many laws, mechanisms and systems have given substance to the idea of human rights since the adoption of the Universal Declaration of Human rights in 1948. But, we have entered a"new" phase in terms of the incorporation of human rights standards into national legal regimes. It can be inferred from this that most human rights abuses can be analyzed and monitored in such a way as to obscure the importance of past patterns of continuity and change. Human rights, in this perspective, are transhistorical.

Secondly, the human rights package has turned into one of the principal instruments of "identifying the emergence of global politics, ${ }^{\prime \prime}{ }^{17}$ expanding politics beyond the state" because they carry normative concerns about individual action into the society of states." ${ }^{18}$ Perceiving human rights as transnational, however, is not always very helpful in understanding the sources of human rights problems in specific contexts as part of a larger historical continuum. Nor does this approach help explain the different responses that the state's diverse levels, branches and factions produce at different time periods to movements defending human rights'cause inside and outside the structures of official politics.

According to the last feature of human rights, violations are a reflection of "difficult" and "exceptional" challenges waged against a regime. Turkey's official view coincides with this view: the few human rights abuses that exist are sporadic, not part of systematic and comprehensive policies of the state. They have grown out of the movements against the existential tenets of the Turkish state, which are secularism, a modern identity and territorial unity. But a more critical inquiry into the republic from different lenses would yield different readings: "the social engineering associated with modernization-from-above was badly flawed from its inception." ${ }^{19}$ The fatal defect was that this was a program "not necessarily committed to all dimensions of modernity," ${ }^{20}$ and not interested in political modernization with the ensuing focus on individual rights, a free and unquestioning public space, a robust civil society, limitation of the state power and the establishment of the rule of law. Secularism as the major leg of the process of social and political engineering acquired a different meaning than in the West. It became a "prerequisite" rather than a "consequence" of having an official identity on equal footing with the West. As a result, it could be argued that historically speaking, the foundational principles of the republic became entangled with the control dimension of politics to the extent of throwing democratic principles-cum-human rights overboard in the name of preserving them.

More still, in the search for the foundational conditions of the existing human rights universe in Turkey, analyzing the Republic's mode of Westernization would be incomplete without relating it to the foundational theory of Republicanism à la Rousseau, which stresses the centrality of the "common good."In general, republican public philosophy is not really con- 
cerned with what human beings universally are. What it defines are the right way of life of the right citizen in the right community (of nation-state). As such, it is not easily decomposable into its constituent individuals. The most privileged position republican public philosophy can afford to human dignity by virtue of being a human being is securing her/him against the assaults of the majorities via equality before the law. It is clear that unless supported by a liberal propensity to accept diversity and difference institutionally and morally, the republican emphasis on unity cannot be reconciled with a human rights agenda easily. It follows from the above analysis that it is not the "difficult" days, but the imperatives of Turkish modernization and the public philosophy, that is, the "good and normal" days, that bear a large responsibility for prioritizing the public over liberal ends.

As democracy and human rights are also tools articulating protest against the abuses in the existing power configuration, oppositional movements using this discourse in the course of Ottoman-Turkish modernization have not always acted to challenge the regime for the purpose of breaking it up. Instead, these movements can be interpreted as part of the normalcy of Turkish modernization process, rather than as anomalies. As professor Kasaba puts it, the movements utilizing the discourses of freedom and rights "dotted the history of Ottoman-Turkish modernization with many uncertainties, occasional reversals, and periodic shifts in its speed and priorities. The important point is to regard these fluxes not as anomalies but as integral parts of the process of modernization itself." ${ }^{21}$

\section{Human Rights and Historical Memory}

A broad literature is beginning to emerge-more so on the Latin American subcontinent-treating the military/authoritarian periods not merely as ruptures in the historical continuum of human rights politics, sooner or later leading to more democratic forms, but as periods worth studying in their own right. ${ }^{22}$ The important point here is that persistent impunity of human rights violations or visible improvements are dealt with by addressing "historical memory."The tenor of analysis in this literature is that the military rule in the 1970s in the Southern Cone of the subcontinent left some imprints on the democracies that followed. Human rights are then used as a political and moral standard to judge the past and analyze how present regimes tackle the past as well as present abuses. The theoretical departure point is the pivotal role attached to "historical memory"by studying compilations of oral histories and written data that organize the memory.

It is true that the destructive war in Turkey's southeast against Kurdish separatism has been won. But the massive damage caused by terror on both sides is not yet told. Turkish scholarship has not largely moved on to 
an historical analysis of human rights violations on the basis of oral histories, psychological profiles, collections of personal letters of and interviews with the perpetrators and victims of human rights violations. ${ }^{23}$ More significantly, there has been no public attempt to erase the memory of the past so as to mend the psychic damage and start a reconciliation process in the society. There is no tradition in Turkey of officially setting up extraparliamentary/independent truth commissions of the kind seen in Latin America, from which"some degree of truth certainly emerged" 24 and some perpetrators of torture, disappearances and extra-judicial killings during the military rule were brought to trial.

True enough, the Latin American Southern Cone went through a relatively more violent form of human rights abuses. The actions and discourses of the civil disobedience movements were extremely vibrant. It can be argued that it is the combination of this intense repression and robust resistance by human rights advocacy groups that played a major part in structuring the "learning process" these societies went through as well as redefining the roles of the successor NGOs and movements at present. It seems that Turkey has not yet come to terms with its historical memory; the republican tradition of prioritizing stability, security and order is more compelling than in Latin America's Southern Cone.

Yet, it would be incorrect to claim that some global human rights norms have not been incorporated into domestic practices. It is important to trace the evolution of Turkey's human rights discourse and practices by welding it to our concern for theory, historicity and contextuality on the levels of state and non-state actors.

\section{Historical Evolution of the Human Rights Regime in Turkey: The Spiral Model?}

Thomas Risse and Kathryn Sikkink draw two clusters of a central core of human rights from the Universal Declaration of Human Rights and develop a spiral model that specifies five stages through which human rights norms and rules are internalized and implemented domestically. ${ }^{25}$ The basic rights they single out are"the right to life"which they define as the right to be free from extrajudicial execution and disappearances; and freedom from torture, arbitrary arrest and detention. Their starting point is that "stable improvements in human rights conditions usually require some measure of political transformation and can be regarded as one aspect of the liberalization process." ${ }^{26}$ The writers, in other words, try to bridge the gap between international relations and comparative politics as well as historical and political analysis. In doing this, they present a theory of the stages and mechanisms through which international norms can lead to changes in the state and civil society. The wider implication of this model is for the international dimension of democratization, an area badly neglected in literature. 
The empirical bases of their analysis is the well-publicized"success stories" of Chile, South Africa, the Philippines, Poland, former Czechoslovakia, as well as more obscure cases of Guatemala, Kenya, Uganda, Morocco, Tunisia and Indonesia. The stages of the spiral model are "repression," ${ }^{\prime \prime \prime} \mathrm{de}-$ nial," tactical concessions," "prescriptive status," and "rule-consistent behavior." The five phases of norm-socialization process in the model are dominated by one of the three modes of interaction: instrumental adaptation to pressures both domestic and global, irrespective of discursive practices; argumentative discourses which agree with their discursive claims, and finally, institutionalization and habitualization of human rights norms. ${ }^{27}$

Drawing on the threads of the Risse-Sikkink model and focusing on the second half of the 1990s when, after the signing of the Customs Union Protocol, human rights came to occupy center space in the national and international agenda, we will test the five-phase spiral model of human rights change in Turkey. The spiral model, however, "does not assume an evolutionary progress toward norm-implementation, but claims to explain variation and lack of progress." 28 Given that it is possible to observe vacillations in human rights policies of the same government, the question then is to problematize the national and global conditions under which the spiral model can be interrupted or reversed.

During most of the 1980s and the first half of the 1990s, Turkish official policy with regard to human rights was engaged in a lengthy "repression" and "denial" discourse. Denial in the spiral model, basically means"the refusal of a government to accept the validity of international human rights norms themselves." ${ }^{29}$ But, in the specific case of Turkey, historical forces have shaped the limits of the denial phase differently: the republican commitment to taking its "rightful" place within the European family of nations has precluded any open rejection of the conceptual validity of human rights. Instead, the government's denial went "further than simply objecting to particular accusations. The norm-violating government charged(s) that the criticisms constitute(d) an illegitimate intervention in the internal affairs of the country." 30 Indeed, framed in this specific argument, the government could maintain a lengthy denial phase, without detracting from its European aspiration. For one thing, official Turkish policy implicitly accepted the validity of global human rights norms but claimed that either the alleged violations did not occur or that they were part of its fight against separatist terrorism within its borders. In claiming this, the government managed to draw some strength from the internationally accepted norm of national sovereignty. An added impetus came from long-held suspicions about European support for the secessionist Kurdish movement, which facilitated the governments' claim that Europe was meddling in a sovereign country's internal affairs. Needless to say, human rights advocacy groups in the 1980s and the first half of the 1990s were relatively weak and their 
international networking was still too modest to effect a change in hegemonic political practice and culture.

The historical limits of the denial stage came with the signing of the Customs Union Protocol, adopted by the European Parliament in December 1995 and coming into effect on January 1, 1996. The protocol itself required that amendments were to be made in political and technical levels to harmonize Turkey's political configuration with Europe. The Customs Union Protocol provided a formal and strategic leverage for the European Parliament to escalate its pressures on Turkey to enter into a new phase in its human rights policies. This phase corresponds to the Risse-Sikkink model's "tactical concessions" and is characterized by three changes: the first is the shift in focus of activities from the transnational to domestic level in terms of strengthening local networks of NGOs and their international linkages. The second feature, according to the model, is the"shaming" process a norm-violating government is subjected to by international actors, backed by material sanctions. Thirdly and more crucially, the government accused of human rights violations gradually moves from a rhetorical discourse to a dialogue with its domestic and international critics over specific accusations..$^{31}$ This is a shift from "rhetorical discourse" to an "argumentative rationality" in which the logic of argument, persuasion and dialogue slowly but surely takes over. The dynamics are such that in arguing over human rights violations in public, the political class is entrapped in its own rhetoric and increasingly turns toward a true dialogue, getting truly engaged in "talking the human rights talk." 32 The most significant point in tactical concessions stage is that "although the norm-violating government might then temporarily improve the situation-for example by releasing prisoners-we do not expect a stable amelioration of human rights conditions... at this point, the repressive government is usually acting almost solely from an instrumental or strategic position, trying to regain military or economic assistance, or lessen international isolation." ${ }^{33}$

The record of the Turkish government since 1995 with regard to the defining characteristics of the "tactical concessions" stage is mixed. But this, in itself, conforms to the ambivalent nature of this stage. On the one hand, the series of governments that came to power in the second half of the decade no longer denied that human rights violations occurred. They took pains, however, to emphasize that they were in the form of aberrant behavior of some security personnel on an individual level, not part of a systematic government policy. In 1996, Tansu Ciller, deputy prime minister and minister of foreign affairs in the Welfare-Path coalition government, admitted the use of torture for the first time in public. ${ }^{34}$ In the same year, a widespread civil protest movement took place in Turkey against the revelation by an accident-called the Susurluk crash-that the state, hand in glove with ultranationalist gangs, was responsible for many irregularities 
involving unknown murders in the southeast, drug trafficking and money laundering. In what was obviously an instrumental move to appease domestic human rights advocates, western governments and agencies, the new government of the post-military intervention era issued directives to prevent torture and continued to reiterate its position to fight against illegal gangs and its commitment to democracy and human rights. In 1997 again, the IHV was accepted as a formal interlocutor by being invited to take part in the meetings of the newly formed Human Rights Coordinator High Council. ${ }^{35}$ Ismail Cem, the Foreign Minister in the present coalition government formed after the 1999 elections; Hasan Denizkurdu, a former minister of justice; Sema Piskinsut, who lost the chairwomanship of Parliamentary Human Rights Commission in October 2000; ${ }^{36}$ Hikmet Sami Turk, former state minister for human rights and current minister of justice; and Mehmet Ali Irtemcelik, a former minister of state for human rights, came to the forefront of the human rights landscape through a more realistic approach to the issue by abandoning the denial policies and showing a keen interest in contributing to the improvement of Turkey's imperfect human rights record.

However, despite the open commitment of the governments in the second half of the last decade to promote human rights and democracy, rhetorical action was more important than argumentative concessions in the tactical concessions phase. Widespread torture prevailed, and perpetrators were either not prosecuted or got away with light sentences. Human rights violations in prison conditions remained grave, journalists were imprisoned, and human rights organizations and activists were subjected to official inquiries. Akin Birdal, who as the chairman of the IHD was the most high-profile defender of human rights cause in public, was critically wounded by unknown assailants on May 12, 1998. After the shooting, the state prosecutor opened a case against him for making"separatist propaganda" in two of his speeches. Still not fully recovered from his injuries, Birdal began serving a 10-month prison term on June 3, 1999 to be released on September 25, 2000 for reasons of poor health. He was back in prison to complete his term on March 28, 2000 to be finally freed on September 23 , the same year.

The rejection of the Turkish candidacy for the EU in the 1997 Luxemburg Summit can be said to have reinforced the process of instrumental adaptation to the pressures on human rights issue, rather than facilitating the argumentation, persuasion and dialogue between the government and domestic and international human rights agencies . More importantly, the Luxemburg meeting epitomized a"shaming"strategy on the part of the EU that was resented by the government and the public, playing into the hands of conservative-nationalist circles. The legacy of a 16-year war that resulted in a militarized state approved by society and unchallenged by the political 
class, as well as sharp polarization between Turks and Kurds, also explains why the tactical concessions stage was imbued more with rhetorical action than "true human rights talk". The characteristic feature of the Turkish context, that is, a politico-legal system which structurally tends to provide impunity to civil and military bureaucrats, has proven to be the major obstacle to a real understanding between the EU bodies and Turkey's civilian-military officials.

In the spiral model, the "tactical concessions" stage is succeeded by a "prescriptive status" phase in which discursive processes of argumentation and persuasion concerning human rights gain a prescriptive status, and beliefs are matched by deeds. The signifiers of this stage are the ratification of international human rights conventions and their institutionalization in domestic law. This is the stage in which human rights are institutionalized irrespective of changes in government and individual leaders, and are perceived"independently from the moral consciousness of actors." ${ }^{37}$ The governments are seen, at this stage, as making sustained efforts to improve human rights conditions. The final phase in the Risse-Sikkink model is characterized by rule-consistent behavior in which human rights norms are so unconditionally institutionalized that norm compliance becomes a habitual practice of actors.

With regard to the Turkish case, while it is clear that we cannot speak of an institutionalization and habitualization process, can we at least argue that the validity of human rights claims has gained a prescriptive status in such a way as to rule out any tactical concessions? Or, does the regime alternate between repression and denial even after it was granted a candidacy status in Helsinki Summit of 1999, which would be an anomaly in the Risse-Sikkink model? Alternatively, have tactical concessions led to a fully mobilized human rights universe with transnational links so strong that pressure from above supplements pressure from below?

There are some hopeful signs in the direction of a transition to a noninstrumental subscription to human rights discourse in Turkey after the Helsinki decision. But a close look at recent developments reveals the persistence of an instrumentalist political will on the part of a ruling strata intent on conserving many of the privileges of a directive bureaucratic state with which it identifies itself, without appearing openly to deviate from the regime's historical affinity with the West. The critical debate at this stage, however, does not revolve around denial of violations of human rights norms. Rather, the discourse of human rights has shifted to the"specificity" argument justifying the suspension and limitation of individual rights in the combat against internal enemies, i.e., irtica and Kurdish separatism, on the grounds that these measures are "exceptional" and "corrective". The army general staff provides the best example of this discourse: it is not true, as has been insinuated by certain circles... that the military exerts its 
authority over the civilian government or has undue influence in civilian political affairs... these assumptions give foreigners the wrong message about Turkish democracy. [But] it must not be forgotten that every country has a system specific to itself." 38

Not denying the existence of global norms impinging on a new democracy discourse that is intertwined with human rights, but reluctant to socialize into and internalize them, Turkey's powerful military bureaucracy, in fact, engages in the process of arguing with its critics. Having said that, however, it is important to note that the Turkish case does not fully conform to the Risse-Sikkink model because of the conscious effort made by the ruling hierarchy not to "talk the human rights talk". Nevertheless, one should keep an open mind to the possibility that over time, the model may be fully operational in fulfilling its implicit assumptions in that despite their conscious intervention, the power wielders may already have been entrapped in an argumentative process whose long-term consequences are neither fully clear to them nor controllable.

As part of the present government's commitment to harmonize the administrative-legal system in line with the Copenhagen criteria, Human Rights Coordinator High Council (Insan Haklari Koordinator Ust Kurulu), a mixed-body of governmental and non-governmental participants, coordinated the drawing up of a national blueprint specifying the necessary amendments over a wide spectrum ranging from the Constitutional amendments to the Criminal Code, the composition of the National Security Council, political parties, human rights education, and the prosecution of public officials. Faced with the heavy criticism of the National Security Council, which bolstered its criticisms with arguments of internal security and the special conditions of the country, in July 2000, the High Council had to "amend the amendments" it proposed originally, in a conservative way.

In July 2000, after a 34-year pause, Turkey signed the International Covenant on Civil and Political Rights and the International Covenant on Economic, Social and Cultural Rights. Because it fulfills one condition of the "prescriptive status" of the Risse-Sikkink model, the act sparked new optimism for a political change of mind and a new will sustained by human rights. Since the first covenant involves recognition of the right to selfdetermination and cultural rights, it immediately raised objections from the conservative-nationalist quarters. It is true that the signing of this particular covenant also mystified those sceptics who have been negatively biased against the existence of a political commitment on the part of the Turkish political class in the direction of a more complete democracy grounded in human rights, least of all in cultural rights. It soon became clear that as it is obligatory for the EU members to sign these two covenants, and more importantly, as Turkey had only taken faltering steps toward structuring her political and social life in conformity with the 
Copenhagen criteria, this is a grand example of a rhetorical action carried out with an instrumentalist logic and aimed at appeasing international pressure agents. Sukru Elekdag, a retired senior diplomat and now a columnist whose views carry serious reflection, interprets this instrumental move in no uncertain terms: "from now on, for all the articles of the covenants that are a source of discomfort for Turkey, the government will put up meticulously prepared, extremely comprehensive reservations before completing the signing process. In reality, this is nothing more than a completely empty symbolic gesture." ${ }^{139}$

\section{Problem 4-Human Rights Advocacy Networks: How To Make Human Rights Relevant?}

In transition from the "tactical concessions"to"prescriptive status"phases, the Risse-Sikkink model depends on local NGO networks and other oppositional groups fully mobilizing and supplementing the pressure from above with pressure from below. In other words, local NGOs and their transnational human rights network links are posited with the task of "pressuring" the governments to comply with human rights norms. Implicit in this model is the assumption that human rights NGOs-in conjunction with international organizations and Western governments-monitor, expose and publicize human rights violations. The question to ask is how realistic this vision of human rights advocacy is in terms of its feasibility to bring about political and social change which is the ultimate end goal of human rights NGOs. In other words, what elements are missing in this model and how well do the Turkish human rights NGOs stand with regard to fulfilling their assumed missions?

The human rights advocacy network in Turkey ${ }^{40}$ has proliferated in recent years. However, two organizations dominate human rights discourse by their domestic and international visibility and unfailing determination to take on politically the most sensitive issues like police brutality, torture, extrajudicial killings, disappearances, forced evacuation of villages in the southeast and the like. The first is the IHD, set up in 1986 with the support of a wide section of left-wing intelligentsia. The IHD established the IHV in 1990. These two groups have developed specializations within the human rights field, each building its strength in a specific direction. The IHV engages in social and legal aid to the victims of human rights violations. More importantly, it extends medical assistance and treatment to torture victims in five torture rehabilitation centers around Turkey employing 40 full-time and 300 voluntary medical experts. Since its foundation, it has treated 4,500 torture victims. A second part of its mission is to act as a clearing house for information on human rights in Turkey by publishing daily and yearly updates containing the names, places, dates and circum- 
stances of each human rights violations. At the time of this writing, the IHV is building a large documentation center in Istanbul that will contain a comprehensive data base, whereas the IHD expends more energy giving legal aid to immediate and individual-level human rights violations by following cases through its provincial branches. It has also set up working groups monitoring a broader range of human rights issues than the IHV.

The assumptions pertaining to monitoring and publicizing functions of advocacy networks can best work in contexts where the education, justice, civil societal and media systems are independent and unco-opted, so that they can mobilize popular support behind the human rights NGOs. In contexts like Turkey, where these elements are lacking, the NGOs are forced to operate in political environments that lack meaningful backing: indeed, they monitor and disclose the human rights situation without the support of Turkey's political parties, trade unions, majority of intellectuals, professional groups, the media and unorganized sectors of the society. One extremely important consequence of this"loneliness" is that they cannot create a genuine commitment among the greater part of the population as they probably miss making human rights relevant to real people's lives. The failure to popularize human rights as a cause also has to do with its legalistic, elitist and abstract discourse. However, it also points at the need for the NGOs to move beyond the mission of monitoring and exposing violations on an individual basis. It shows the need to seek ways to amalgamate activities for raising the public's consciousness with empowering and integrating ordinary people into human rights discourse.

The IHV is inflicted with the same lack of community support. But it presents the muted nature of the support behind it as a useful "strategy" on its part-not to provoke the wrath of the government so as to close its treatment centers. ${ }^{41}$ The IHD, on the other hand, has a different problem in terms of its level of grassroots support: this NGO is somewhat identified in the minds of most people with Kurdish activists, Alevis and left-wing groups. Empirical evidence also lends support to the prevailing conviction that the IHD suffers from an overrepresentation of Kurdish interests and leftist cliques much more so than the IHV. It is believed that the IHD reduces Turkey's human rights problem to the Kurdish question steeped in a leftist language. The difficulty with the dominant notion that the IHD tends to automatically converge the Kurdish issue with leftist theses to the exclusion of much of everything else is that it arouses popular hostility, fuels the fire of right-wing demagoguery on human rights, and increases the likelihood of government repression.

A further consequence of the general lack of popular affinity with human rights advocacy groups in Turkey is their turn to international organizations, which works to the further detriment of building the NGOs as effective grassroots organizations that do not rely on foreign funding, sup- 
port and sympathy to have an impact in their own country. It is a fact of life that strained with a tight budget and the high costs of maintaining a rich profile of activities sustained by sufficient manpower--not to mention their vulnerability to governmental manipulation-human rights NGOs in nonWestern contexts rely on foreign sponsorship to survive. The IHV, for instance, is totally funded by outside sponsors: donors are the European Commission, the Swedish Support Committee for Human Rights in Turkey, the United Nations Volunteer Fund for Victims of Torture and other small contributions from support committees abroad, most notably from Scandinavia. It should be noted that that part of the funds provided for the IHV goes to finance the activities of its sister organization, the IHD.

One immediate disadvantage of this financial dependence on outside sources seems to be the way it reinforces their alienation from the native milieu. But that is not all. It has already been noted that donors' agendas are often centered on self-interest. This seems to create a serious clash of interest between the Turkish NGOs and their foreign donors. Native NGOs feel that Turkey's failings on the human rights score are overlooked by Western donors to promote their own economic, political and military interests: "the image of improvement is strongly endorsed by the EU and the USA. Factual data, on the other hand, point to new trends in violations... the issue of human rights violations in Turkey started to decline on the European agenda... but the question remains to be asked: does this process have positive effects on the lives of real persons living in Turkey?" 42

The imposition of patronage,"in the words of IHV chairman Yavuz Onen, by international donors and even by NGOs from less-developed countries "in the name of support," ${ }^{43}$ highlights a more profound disagreement pertaining to the ideological orientation of western bodies and the Turkish human rights advocacy groups. This is a left-right divide on a global level. The IHV and the IHD are critical of the strong influence of the ideas of the free market and of the state's withdrawal from overseeing distributional justice in their donors' and supporters'agenda as not providing hospitable conditions for fostering the spirit of human rights. ${ }^{44}$ On the other hand, the IHV spends most of its scarce resources and time to produce reports, maintain a large mailing list, and ask its scant staff to provide answers to the questions posed by foreign delegations and foriegn diplomats seeking information about the human rights situation. One could argue that the pay off is a linkage with the global human rights community which, ultimately, forms the most effective pressure point for any improvements in human rights situation in a country like Turkey. Paradoxically, however, for the IHV official I interviewed, the ideological difference between the Turkish and global human rights universe is a major source of concern that seems to preclude the development of a genuine sense of "kindred souls" between them. 


\section{Conclusion}

Despite their strong transnational links and support in the second half of the 1990s, Turkish NGOs have not yet had a "tremendous" impact on domestic political and social change. But new points of contact have been established in the public sphere between governmental agencies and the IHV and IHD, with both sides engaged in an argumentative process, which may, in the long run, lead to the subscriptive phase of "human rights talk" and deed. The general tenor of this essay may lend itself to suggesting two prerequisites for establishing such a sustainable human rights regime in this geography: the first is "capacity building", the other is grounding this regime in an accurate perception of the structures of power, domestic and international, so as to "integrate" the human rights bundle into all aspects of life, at all levels, within all traditions and institutions by empowering the community into the language of human rights. Most of all, integration of human rights into a liberal democratic order requires coming to terms with the past.

Capacity building can be defined in different terms: in the words of Mary Robinson, the UN High Commissioner for Human Rights, it is"facing-up to the bullies." ${ }^{45}$ It is a cliche that the legalistic entrenchment of human rights is sufficient guarantee against their violation. It is almost unrealistic to expect a system to volunteer to set up a human rights regime that will limit and cripple the power it wields. So, what to do? Mary Robinson suggests a "national plan," as opposed to fragmented political notions, building a sustainable model with strong bricks and mortar. As Robinson notes, "even where there are plans, plans without effective strategies for implementation are empty vessels." ${ }^{46}$ We could add more: in contexts like Turkey where "special circumstances" provide the pretext for legitimating an anti-human rights discourse, Mary Robinson's national plan's chances of success depend on building a strong survival capacity for any civilian government that works to bring itself, the urban middle classes, civil society and the military into the realities embedded in human rights.

\section{Notes}

1. Stanley Fish," Boutique Multiculturalism, or Why Liberals Are Incapable of Thinking About Hate Speech?" Critical Inquiry, 23, 2 (Winter 1997), p. 381.

2. Human Rights Foundation of Turkey," Human Rights Situation in Turkey: New Trends," February 2000, mimeo, pp. 4-12.

3. In the above report, crimes against the right to life is broken down into six sub-categories: extrajudicial killings (declining since 1996), unknown political murders (declining since 1994), disappearances (declining since 1994), deaths in incommunicado detention (in custody or prison) (declining since 1996), civilians killed in explosions of mines (declining since 1994) and killings of non-combatant civilians by armed assailants (declining since 1993). 
4. "Human Rights Abuses and Torture Back on the Agenda,"Turkish Daily News, March 8, 2000.

5. Rick Johnstone, "Liberalism, Absolutism and Human Rights: Reply to Paul Gottfried," Telos, 116 (Summer 1999), p. 140.

6. Hukukun Ustunlugu, Demokrasi, Insan Haklari- Sivil Toplum Orgutleriyle Duzenlenen Calisma Toplantisi, 14 Ekim 1999 (Basbakanlik Basimevi: Ankara, 1999).

7. Ioanna Kucuradi,"' World Problems'from theView-Point of Human Rights,"in Ioanna Kucuradi, ed., Papers Presented to the International Seminar on Philosophy Facing World Problems ( Philosophical Society of Turkey: Ankara, 1986), pp. 57-71.

8. Ioanna Kucuradi," Human Rights: the Idea, Demands and Instruments, " in Ioanna Kucuradi, ed., The Idea and the Documents of Human Rights (international Federation of Philosophical Societies and the Philosophical Society of Turkey: Ankara, 1995), p. 76.

9. Ioanna Kucuradi," World Problems from the View-point of Human Rights," p. 57.

10. Thomas Risse, "International Norms and Domestic Change: Arguing and Communicative Behavior in the Human Rights Area," Politics and Society, 27, 4 (Dec. 1999), p. 287.

11. Interview with Bulent Peker, member of the IHV's general executive council and head of the Documentation Center, August 4, 2000, Ankara.

12. Quoted in Risse, "International Norms and Domestic Change...,", p. 548.

13. "Devlet Bakani Mehmet Ali Irtemcelik'in Toplantiyi Acis Konusmasi," in Hukukun Ustunlugu, Demokrasi, Insan Haklari, p. 6.

14. According to a new public opinion survey conducted by Piar-Gallup between 10-21 August 200 and published on September 21,2000,69.3 percent of the respondents believe that full membership in the EU will directly cause economic prosperity, enhance democracy and raise human rights to universal standards. See Sukru Elekdag, "Aklimiz Avrupada," Milliyet, Sept. 21, 2000.

15. "MHP: AB Arac," Radikal, Sept. 9, 2000.

16. The Economist, A Survey of Turkey, Ataturk's Long Shadow, June 10, 2000.

17. John Vincent,"Modernity and Universal Human Rights," in Anthony G. McGrew, Paul G. Lewis et.al., eds., Global Politics, Globalization and the Nation-State (Polity Press: Cambridge,1992), p. 269.

18. Ibid., p. 289.

19. Caglar Keyder, "Whither the Project of Modernity? Turkey in the 1990s, "in Resat Kasaba and Sibel Bozdogan, eds., Rethinking Modernity and National Identity in Turkey (University of Washington Press: Seattle and London, 1997), p. 38.

20. Ibid., p. 39.

21. Resat Kasaba," Kemalist Certainities and Modern Ambiguities,"in ibid., p. 20

22. A representative example of this approach is by Louis Bickford, "Human Rights Archives and Research on Historical Memory: Argentina, Chile and Uruguay," Latin American Research Review, 35, 2 (Autumn 2000).

23. One notable exception is a book based on the oral histories of the former conscripts of the Turkish army fought in the war. The distribution of the book, however, was banned and the state prosecutor opened a case against the author. The case finally resulted in her acquittal in October 2000. See Nadire Mater, Mehmed'in Kitabi: Guneydoguda Savasmis Askerler Anlatiyor (Metis Yayinlari, Istanbul, 1999).

24. Bickford, Human Rights Archives and Research..., p. 162.

25. Thomas Risse and Kathryn Sikkink," The Socialization of International Human Rights Norms into Domestic Practices: Introduction," in Thomas Risse, Stephen C. Ropp and Kathryn Sikkink, eds., The Power of Human Rights, International Norms and Domestic Change," (Cambridge University Press: Cambridge, 1999), pp. 2-3.

26. Ibid., pp-3-4.

27. Ibid., pp. 12-14.

28. Ibid., p. 34 .

29. Ibid., p. 23.

30. Ibid.

31. Ibid., pp. 25-28. 
32. Ibid., p. 27.

33. Ibid., p. 25.

34. 1996 Turkey Human Rights Report (IHV Publication 18: Ankara 1998), p. 11.

35. Turkiye Insan Haklari Raporu 1997 (IHV: Ankara, 1999), p. 97.

36. Sema Piskinsut entered into the parliament as a Democratic Left Party deputy from the Western province of Aydin in April 1999 general elections. Her chairwomanship of the Parliamentary Human Rights Commission deserves special reference: it is through her unflinching idealism and commitment to the cause of human rights that the commission adopted an energetic and high-profile approach to human rights abuses, drawing the public's attention and raising consciousness on the issue in the last year. The commission members travelled to the farthest corners of the country to investigate and gather data on the state of human rights by way of talking to the victims of human rights violations and making unannounced visits to prisons and police stations. The seven reports published (two are in the process of being prepared) on various aspects of human rights, especially on torture, caused waves of discomfort among the security milieu, political class and bureaucrats who have a stake in the existing system of irregularities with regard to human rights. One unorthodox method Sema Piskinsut used in disclosing these irregularities was to confiscate the torture equipment she found in one of the police stations the commission visited and put them on display in her office in the parliament. The interesting point about her dismissal from the position of the chair of the commission was that it was brought to the public's notice that it was on the wish of Bulent Ecevit, her party leader, that she was removed and the post was offered to the Nationalist Action Party, the ultranationalist coalition partner.

37. Risse and Sikkink, The Socialization of International Human Rights Norms..., p. 17.

38. "The Military Reiterates That It Is The Protection of Democracy," Turkish Daily News, November 25, 1999.

39. Sukru Elekdag,"Ici Bos Sembolik Bir Jest," Milliyet, August 21, 2000/

40. In what follows about the Turkish human rights organizations, I am indebted to Bulent Peker as well as some anonymous speakers from the human rights universe for the factual data provided on IHV and IHD.

41. Interview with Bulent Peker.

42. Human Rights Situation in Turkey, New Trends, p. 1. Also see Yeni Bin Yila Bakarken Turkiye Insan Haklari Hareketi Konferansi Nihai Rapor ve Sonuc Bildirgesi, 4-5 Aralik, 1999, Ankara, p. 7. European Union Commissioner Gunter Verheugen's expression of satisfaction during his last visit to Ankara that he was happy with Turkey's progress toward meeting the EU membership criteria since the Helsinki Summit may be taken as a substantiation of the clash of agendas. See "Verheugen Pleased with Turkey's Progress,"EurActiv (EU News Policy, Positions and Contacts Online) Internet.

43. Yavuz Onen's letter to Mary Robinson, the UN High Commissioner for Human Rights, mimeo., Dec. 7, 1998, p. 2.

44. Ibid., p. 3.

45. Mary Robinson, "Human Rights, Challenges for the 21st Century," Development Dialogue, 1 (1998), p.13.

46. Ibid., p. 11. 